\title{
Algumas vozes do mundo na poesia portuguesa pós-1961
}

\author{
Some wordly voices in \\ Portuguese poetry post-1961
}

Paulo Braz ${ }^{1}$

\section{Resumo:}

O ensaio busca descrever um percurso crítico em torno de alguns nomes destacados da poesia portuguesa pós-1961, tendo como mote principal a discussão em torno da condição mundana em que ela se implica, ao que se pode inferir a influência de certas correntes da modernidade baudelairiana a partir da imagem da queda e da profanação.

Palavras-chave: Poesia portuguesa contemporânea. Mundo. Profanação.

\begin{abstract}
:
This essay follows a critical path around some prominent poets of portuguese poetry post-1961 and discusses the worldly condition in which it is involved so that it is possible to recognize the influences of certain aspects of Baudelaire's tradition of modernity through the image of fall and desecration.
\end{abstract}

Keywords: Contemporary portuguese poetry. World. Desecration.

Segundo algumas correntes religiosas, sobretudo aquelas ligadas ao cristianismo, diz-se do mundo a tudo que, por seu caráter profano, pode afastar os fiéis da verdade sagrada de seu Deus. Evidentemente, o que é $d o$ mundo é, claro, mundano e, portanto, sujeito às alterações imprevisíveis da

1 Professor do Setor de Teoria da Literatura da Universidade Federal de Pernambuco (UFPE) e coordenador do grupo de pesquisa deriva. 
vida material e à finitude.

Sabe-se também que tal concepção, tão arraigada no inconsciente coletivo do sujeito ocidental, em muito deve à dicotomia platônica que separa o universo de conhecimento entre dois "mundos": o sensível, aquele a que se pode aceder por meio dos sentidos corporais e que corresponde ao plano material; e o inteligível, também chamado o mundo das ideias, cujo acesso é permitido apenas ao intelecto, de onde se conclui a tarefa privilegiada do filósofo, este que é vocacionado a tão nobre função. Há naturalmente uma hierarquia em jogo, sendo o mundo sensível rebaixado à condição de cópia imperfeita do mundo inteligível, espaço onde se entronam a forma do Verdadeiro, do Justo e do Belo.

Tal enquadramento filosófico moldou não somente o nosso modo de pensar no campo das ciências (mesmo as modernas) como determinou, bem ou mal, a nossa orientação estética, de maneira que, até hoje, não é de se espantar que o gosto médio de um apreciador da arte - seja ela qual for - se afina a uma perspectiva espiritualizada da criação. Os românticos, que tanto almejaram a expressão do sublime em arte, que o digam - assim como a herança deixada por eles e que, em alguma medida, atravessou todo o século XX.

Em poesia, especificamente (pois que é o que, aqui, mais nos interessa), o esforço dos modernistas focou-se, em boa parte, na dissolução de tais paradigmas estéticos, o que desencadeou, em muitos casos, uma perversão das formas poéticas, quando não a sua pura denegação, levando a criação artística aos limites do informe ou para além dos limites entre as formas no encontro de diferentes gêneros. $\mathrm{O}$ caso português - a que neste ensaio me dedicarei com exclusividade - tem, na obra de Fernando Pessoa, e, de um modo geral, nos autores envolvidos na publicação de Orpheu, um lugar privilegiado de experimentação e revolução dos modelos poéticos pré-concebidos. Não é o caso de avançar sobre exemplos que justifiquem tal afirmativa, uma vez que o espaço deste ensaio não me permitiria uma 
abordagem tão ampla do problema que desejo delinear, porém destaco o texto em prosa de Pessoa "Apontamentos para uma estética nãoaristotélica", em que o poeta fingidor desmonta as bases de uma concepção mimética da arte, que visa à beleza como finalidade maior da criação, em prol de uma noção de estética "baseada, não na ideia de beleza, mas na de força" (PESSOA, 2005, p. 240).

Sobre o que quer dizer Pessoa com tal ideia de força, o seu texto explica que a poesia se deve orientar por processos inventivos que encontrem na vida física (ou mesmo fisiológica) o seu modelo de atuação. Um poema é, portanto, um organismo vivo e, como tal, submete-se às intempéries do mundo - e, como todo corpo vivente, está também sujeito às leis da morte.

A revolução de Orpheu nos concede essa visão do poema como organismo, sistema, ou, se quisermos, objeto autônomo de arte - revolução que respinga, uma década depois, nos (talvez excessivamente idealistas) poetas críticos de presença. Estes, leitores de primeira hora da poesia de Fernando Pessoa e companhia heterônoma, assim como de Mário de SáCarneiro, Almada Negreiros etc., trarão consigo um sentimento muito candente de afirmar, igualmente, uma "literatura viva". Faço referência, é claro, ao ensaio-manifesto escrito por José Régio que abre a primeira página do primeiro número da revista de Coimbra: "Em arte, é vivo tudo o que é original. É original tudo o que provém da parte mais virgem, mais verdadeira e mais íntima duma personalidade artística." (RÉGIO, 1927, p. 1). Está posto, entretanto, o equívoco! Viva, sim, diz-se essa literatura, mas tão presa a um tal culto da personalidade criadora que, ao tentar traduzir os anseios libertários da imaginação órphica, trai a sua própria intenção de vanguarda, ao replicar lugares comuns do pensamento romântico, temperados com um quê de angústia religiosa e de certo psicologismo advindo das leituras recentes da obra de Sigmund Freud.

Os anos 1940 acompanharão toda a querela ideológica entre 
neorrealistas versus presencistas - discussão que, afinal, nos trouxe bons contributos críticos para compreender o cenário poético português, naquele princípio de século XX, em franca tensão com as demandas políticas, tão urgentes nos anos de chumbo da ditadura salazarista. Os poetas do dito Novo Cancioneiro propõem-se, aqui, a uma investida radical na escrita de textos cuja finalidade comunicativa se orientava à denúncia das atrocidades promovidas pelo sistema de governo naquela altura. Vislumbrava-se, então, nesse que foi um dos movimentos mais importantes para o delineamento da poesia portuguesa novecentista, a possibilidade de formular (de tal modo, como nunca antes foi feito) uma poesia política, o que, a meu ver, trará em definitivo a palavra poética para o mundo.

Em sintonia com tais discussões, mas à parte de movimentos e filiações literárias, nomes fortes, como são os de Sophia de Mello Breyner Andresen e Jorge de Sena, conquistaram em sua poesia uma das expressões mais veementes desse sentimento do mundo. A atitude testemunhal reivindicada pela palavra seniana revelará o desejo de fazer do poema um lugar comum, espaço de encontro e diálogo em que se faz o jogo políticopoético: "Sento-me à mesa como se a mesa fosse o mundo inteiro" (SENA, 2010, p. 45).

Em conformidade a essa perspectiva crítica, Sophia busca a justa forma em que as palavras e os dias encontram o seu equilíbrio no arco do poema: "Aquele que vê o espantoso esplendor do mundo é logicamente levado a ver o espantoso sofrimento do mundo. Aquele que vê o fenómeno quer ver todo o fenómeno. É apenas uma questão de atenção, de sequência e de rigor." (ANDRESEN, 2018, p. 365). Como nota a autora de $O$ nome das coisas, "atenção", "sequência" e "rigor" constituem, em outras palavras, uma postura ética, isto é, um modo de construir verbalmente o seu estar no mundo, sem trair o que do mundo é "esplendor" ou "sofrimento". Aliás, essa atitude simpática da poesia andreseniana é o que, afinal, promove um sentimento de compaixão com tudo o que é humano - baixo ou elevado - e 
determina o seu anseio por justiça, na medida de nossos mundanos valores.

A aventura surrealista, nos tardios anos $1950 \mathrm{em}$ Portugal - apesar do já desgastado embate entre os muitos campos de força do ambiente literário português que insistiam em denegar qualquer qualidade poética aos neorrealistas, acusados de aparelhamento ideológico-partidário nas suas obras -, soube com primazia esclarecer esse mistério em que palavra e mundo, afinal, se fundiam e eram um só. A imaginação criativa de autores mais ligados ao movimento, como é o caso de Mário Cesariny, assim como a visão crítica de poetas-ensaístas contemporâneos, caso de António Ramos Rosa, deixaram uma bela lição aos poetas vindouros que fariam dos anos 1960 (e, especificamente, 1961) um dos períodos mais profícuos da poesia portuguesa.

Não obstante esse (porventura excessivamente longo) prólogo, o que eu gostaria de deixar claro é que, em meio a esse quadro de tensões entre as muitas correntes de força da poesia portuguesa na primeira metade do século XX, é possível reconhecer mais ou menos uma constante tentativa de determinar o valor poético como algo intrinsecamente voltado para o mundo. Esse fato não é em nada fortuito e se liga ao que foi dito no início deste ensaio, o que talvez possa ter deixado pontas soltas aos olhos do leitor. Dizia eu, no primeiro parágrafo, que do mundo são as coisas profanas, que tentam e pervertem a consciência do fiel, a qual se deveria voltar exclusivamente para o que é sagrado. Diante do que se expõe, vale lembrar que, já em meados do século XIX, se constituía uma tradição da modernidade com Charles Baudelaire e a sua obra Les fleurs du mal que revolucionou o modo de se pensar e fazer poesia ao conduzir a sagrada dimensão do poético para o chão imundo da cidade, realizando um dos mais vertiginosos movimentos de queda a que se assistiu na história da cultura ocidental. Baudelaire, com efeito, é uma figura incontornável, no contexto do universo burguês, para a compreensão desse processo de "mundanização" da poesia, no sentido mesmo de secularizar o que era 
votado às altas esferas do pensamento. Giorgio Agamben, em "Elogio da profanação", declara que "[...] se consagrar (sacrare) era o termo que designava a saída das coisas da esfera do direito humano, profanar, por sua vez, significava restituí-la ao livre uso dos homens." (AGAMBEN, 2007, p. 57). Ora, podemos afirmar que Baudelaire, ao deixar a sua aura de poeta cair na lama, opera um verdadeiro gesto profanatório - gesto que, para as gerações futuras, não passaria em vão.

A poesia portuguesa decerto bebeu dessa fonte que, passando por Cesário Verde e Álvaro de Campos, se consolidou no século XX. Portanto, nosso objetivo é justamente descrever um percurso poético destacando autores que, publicados a partir de 1961 e imbuídos do conhecimento histórico da moderna poesia portuguesa pós-Pessoa, investem a sua escrita de uma radical prática de investigação crítica do mundo, seus problemas e contradições. Como ficará mais evidente no desenrolar deste trabalho, por mundo compreendemos não só o mundo profano, ou seja, aquela esfera do real que diz respeito intrinsecamente ao humano e, em específico, às suas relações de trabalho e produtividade, mas também aquela parcela de ócio em que contemplação e tédio dão azo a descrições de um cotidiano reles, ainda que, muitas vezes, cheio de significado simbólico. Por outro lado, iguamente trataremos de um amor do mundo, com poetas que concentraram a sua experiência de escrita na exploração do desejo carnal como modo revolucionário de debater hábitos socialmente aceites (na cama ou fora dela). E, por fim, sabendo que sagrado (em oposição ao mundano) é tudo aquilo que está separado do plano profano, e que se volta a um tipo especial de uso, pois que é dedicado aos deuses, buscaremos, nessa tensão entre sagrado e profano, apontar a possibilidade de formulação de um fazer poético que, sem se desligar do mundo, encontra tangências com a esfera do sagrado.

Não é nenhuma novidade assinalar o mágico ano de 1961 para a poesia portuguesa, tendo em vista a profusão de publicações que 
determinariam o futuro de autores incontornáveis para um entendimento mais amplo do que significaria o ambiente literário da segunda metade do século XX. Rosa Maria Martelo, em seu Vidro do mesmo vidro: tensões e deslocamentos na poesia portuguesa depois de 1961, descreve um dos mais agudos apontamentos sobre a relevância dos poetas de 1960 para o desenvolvimento da poesia nas décadas subsequentes. Em outros textos esparsos, a ensaísta dedicou-se igualmente ao exercício de compreensão do que supostamente caracterizava o novo período histórico ou se era possível falar em ruptura estética. Em "Antecipações e retrospectivas: a poesia portuguesa na segunda metade do século XX", após ressaltar a inegável importância de "Uma literatura desenvolta ou os filhos de Álvaro de Campos", texto de Eduardo Lourenço, Rosa Martelo declara que, naqueles anos 1960 ,

a poesia portuguesa se encaminhava para uma radicalidade discursiva que prescindia da comunicabilidade mais imediata, circunscrevendo no espaço da inquirição da língua e da desestabilização da gramática o questionamento das formas de poder e de repressão, bem como o esforço de conquista de um mundo e de uma subjetividade mais livres. (MARTELO, 2006, p. 131)

Gostaria de destacar, está evidente, a asserção de Rosa Martelo referente ao "esforço de conquista de um mundo e de uma subjetividade mais livres". Em Portugal, o ano de 1961 assiste a um dos mais sombrios momentos da ditadura salazarista, com a eclosão da guerra colonial e o envio em massa de jovens marcados para morrer em África em um confronto geopoliticamente absurdo. A discussão sobre as relações de poder, tão desiguais em tempos de censura e radical reacionarismo, está em voga e surge plasmada na letra daqueles poetas que, segundo a ensaísta, optam por uma estratégia "discursiva que prescindia da comunicabilidade mais imediata". Em outras palavras, Rosa Martelo assinala um reencontro 
com certa vertente da modernidade centrada na textualidade do poema - textualidade, entretanto, profundamente vocacionada a repercutir os problemas do seu tempo histórico.

Antes dela, outros críticos (e poetas-críticos) igualmente se dedicaram a pensar tal panorama poético. Gostaria de destacar um deles: Gastão Cruz. O autor de $A$ morte percutiva assina também o livro de ensaios $A$ vida da poesia. ${ }^{2}$ A obra crítica descreve um percurso analítico da poesia portuguesa, pelo menos desde Cesário Verde até as mais recentes produções de novíssimos poetas do século XXI, mas é inegável o protagonismo concedido aos seus contemporâneos dos anos 1960, assim como a alguns dos seus predecessores - mestres que prepararam o terreno para o inventivo campo de experimentações vindouro.

Gastão, poeta que, antes de tudo, é estreado na plaquette de Poesia 61 , testemunhou do seu tempo com o olhar crítico que soube dele subtrair a expressão dolorosa de um mundo doente. Doença do mundo, doença da linguagem: na tangência entre essas duas instâncias, é possível notar a construção de um pathos verbal capaz de repercutir o espírito do tempo:

Hoje sei como se exprime a vida da poesia com a sinceridade das emoções linguísticas com que o mundo devasta e enche as nossas vidas

Aprendi a clareza das imagens fictícias recolhidas na luz do corpo nu e vivo entre os golpes orais errante desferidos (CRUZ, 1983, p. 156)

O poema de Campânula, além de ser uma arte poética cujo título (“A vida da poesia”) anos depois irá rebatizar o seu livro de ensaios, não

2 A princípio, essa antologia de ensaios sobre poesia portuguesa moderna e contemporânea vinha publicada com o título $A$ poesia portuguesa hoje. 
deixa de ser, também, uma resposta aos tantos equívocos gerados em torno das intenções criativas dos autores surgidos nessa geração. Trato, especificamente, das querelas protagonizadas por Joaquim Manuel Magalhães e de toda a discussão relativa ao famigerado "regresso ao real", na qual o autor de Os dois crepúsculos por um tempo insistiu ${ }^{3}$. Creio tratarse de um falso problema, ainda que a sua existência, por si só, torne válida a menção. A dita "sinceridade das emoções linguísticas" nos expõe um verdadeiro problema de representação no âmbito da linguagem, em que a expressão poética se encontra a meio caminho entre o que se diz e o que se sente.

Aliás, esse lugar entre que acabo de destacar é grosso modo aquele que encontramos nos versos de "Princípio", de Joaquim Manuel Magalhães, quando proclama no seu poema-manifesto: "Voltar junto dos outros, voltar/ ao coração, voltar à ordem/ das mágoas por uma linguagem/ limpa, um equilíbrio do que se diz/ ao que se sente [...]" (MAGALHÃES, 1981, p. 13, grifo nosso). Não se trata de rasurar as diferenças flagrantes entre as poéticas de Gastão e Magalhães, mas procuro, aqui, rastrear, na dessemelhança, o que atravessa, no caso, ambas as obras no sentido de uma procura incansável por essa fidelidade ao mundo. Evidentemente, são muitos os modos de dizê-lo, o mundo, e os tempos, assim como as vontades, mudam a sensibilidade do poeta que, a cada geração, refere-o afinado à sua sensibilidade de artista. Se Gastão canta um mundo devastado, manifestando-o à medida do que pode uma linguagem em ruína, igualmente devastada, a expressão lírica de Magalhães avança no sentido de dizer a "catástrofe", o "abismo" e o "terror" na "afirmação das palavras comuns" (MAGALHÃES, 1981, p. 13).

Não obstante as diferenças estéticas, reconheço no percurso da poesia portuguesa (pós-1961, em especial) um anseio candente por se

3 Para um maior aprofundamento nesse aspecto, ver o meu "Do mundo de António Franco Alexandre e o problema do «regresso ao real»". Pensares em revista, São Gonçalo, nº 2, p. 180-198, jan/jun 2013. 
voltar às coisas do mundo mais ordinário, ao real, como diriam o autor de Os dias, pequenos charcos e também o próprio Gastão: “[...] na nota que escrevi para acompanhar a recolha poesia 1961-1981, dizia: «Sempre me considerei um poeta realista.» Tenho [...] sérias dúvidas sobre a validade desta classificação; melhor seria, talvez, dizer «poeta do real»." (CRUZ, 2008, p. 364). A declaração, que pode parecer ligeiramente vaga, é decerto mais esclarecida à luz da leitura da poesia gastoniana, sobretudo se acompanhada dos comentários críticos que tece sobre os seus companheiros de geração.

Notemos, por ocasião, uma sua companheira de Poesia 61: Luiza Neto Jorge. A respeito da poeta de Quarta dimensão, o autor farense, com alguma reverência, afirma, apresentando-a, que

[...] é, sem dúvida, uma grata incumbência, [...] penetrar, de novo, procurando descrevê-lo e caracterizá-lo, num dos mundos mais fascinantes criados na poesia portuguesa, e não digo apenas na do século $\mathrm{XX}$, embora o mundo de Luiza seja tão representativo desse tempo magnífico, em que todo um vasto conjunto de autores apresentou uma variedade de propostas que continuam a parecer-nos fortes e actuais. (CRUZ, 2010, p. 31)

A poesia de Luiza não é tão só poesia, mas também mundo. Um mundo, dos mais fascinantes, porque feito de linguagem em estado convulso, conforme a sensibilidade da poeta. Com efeito, aquele que buscar pactos de leitura de tipo realista na obra de Luiza Neto Jorge se decepcionará. O próprio Gastão, na sequência do que diz do mundo de Luiza, revela a sua admiração pela poesia jorgiana ao destacar "a carga expressiva de um estilo de enorme concentração verbal e metafórica, apoiada num domínio magistral do ritmo e numa espécie de espontâneo e evidente recurso à elipse.” (CRUZ, 2010, p. 31). Ora, todas as características elencadas pelo ensaísta focam a sua atenção ao que, no mundo de Luiza, é fenômeno 
verbal. E, no entanto, não há grande contradição nessa assertiva.

Em um de seus mais belos poemas, "Magnólia”, Luiza Neto Jorge leva aos extremos a fusão entre palavra e matéria, ou a elisão da palavra na matéria: "Um diminuto berço me recolhe/ onde a palavra se elide/ na matéria - na metáfora -/ necessária, e leve, a cada um/ onde se ecoa e resvala." (JORGE, 2001, p. 137). Na tensão entre natureza e cultura, a flor da poesia, flor magna, magnólia, reduz-se à condição de som diminuto; mas é também sussurro que no ouvido do leitor pode soar exaltadamente pronunciado. É então que a flor renasce "um mínimo ente magnífico" (JORGE, 2001, p. 137). Esse pouco ou nada que a palavra evoca, apesar de sua rudeza e brevidade, não nega o desejo de se elidir "na matéria", na metáfora-mundo.

Estreitemo-nos um pouco mais da relação poética de Luiza com a expressão de um mundo cotidiano. Para tanto, trago à baila fragmentos das primeiras estrofes do poema "Acordar na rua do mundo":

madrugada. passos soltos de gente que saiu com destino certo e sem destino aos sonhos no meu quarto cai o som depois a luz. ninguém sabe o que vai por esse mundo. que dia é hoje? soa o sino sólido as horas. os pombos alisam as penas. no meu quarto cai o pó.

um cano rebentou junto ao passeio. um pombo morto foi na enxurrada junto com as folhas dum jornal já lido. [...] (JORGE, 2001, p. 284)

A cena descrita nesse excerto de poema expõe-nos uma profusão de sentidos experimentados pelo eu lírico que, de dentro do seu quarto, em casa, assiste ao mundo que, da sua rua, invade-o com o assombro das 
coisas que transfiguram a consciência de alguém que acorda. Um acordar, entretanto, em desacordo, digo, em atrito com o mundo que, por sua qualidade intrínseca, é precário e passageiro: "soa o sino sólido as horas. os pombos/ alisam as penas. no meu quarto cai o pó." O tempo, fenômeno abstrato, concretiza-se no mundo por meio do som do "sino sólido" (grifo nosso) que bate as horas; concomitantemente, no "quarto cai o pó". O quadro se desenvolve quando se nos apresenta a imagem de "um pombo morto" que é levado pela "enxurrada/ junto com as folhas dum jornal já lido". A natureza morta mantém-se no contínuo de um fluxo vital a que o sujeito lírico não acessa, pois que, ser mortal, é detentor de uma razão descontínua cujo limite do conhecimento está encerrado pelo que pode o seu corpo vivo. Além da vida, só é possível especular às cegas a noite da morte. Notemos que a cena se dá de "madrugada", no mais escuro da noite, quando o sujeito lírico é atravessado pelo mundo que entra pela janela: "ninguém sabe o que vai/ por esse mundo."

Creio ser válido destacar um pequeno dado "geo-biográfico": Luiza Neto Jorge morou na região do Chiado, no Centro de Lisboa, na então chamada Rua do Mundo, curiosamente hoje denominada Rua da Misericórdia. O piedoso batismo, no entanto, não nos subtrai da memória os esforços de uma obra que corajosamente sempre se impôs contra os poderes. E o poder, entendemos com Roland Barthes, é uma instância gregária (BARTHES, 2013, p. 13). Se quisermos transferir o vocabulário crítico para uma esfera filosófico-religiosa, poderíamos chamar ao poder um fenômeno transcendente, porque a transcendência estabiliza, sublima a dinâmica volúvel do mundo na paralisia da Ideia. O poder que, no âmbito discursivo, permeia a língua e nos "obriga a dizer" não dá espaço para a inquirição ou para a dúvida, muito menos para a violência de uma desagregação dos sentidos tal qual ocorre na poesia jorgiana sítio excessivamente movediço para que ele possa executar a sua força imperiosa. 
Outra voz que fez da inquirição do mundo cotidiano um móvel potente para a sua poesia é a de Ruy Belo. Autor inaugurado igualmente no de 1961 com o seu Aquele grande rio Eufrates, é decerto uma figura decisiva no delineamento do quadro da poesia portuguesa da segunda metade do século XX. Com uma poética bastante distinta da de Luiza, que, ora vimos, optava por soluções estilísticas de uma contenção linguística que culminava em elipses radicais, Ruy Belo avança na construção de uma escrita que se avoluma na prolífica extensão do verso ao ponto de tocar os limites da prosa. Mas dizer que a obra de Belo tem um quê de prosaico não implica de modo algum recusar a ela a concentração verbal própria da poesia. Muito pelo contrário, o que desejo expor com essas asserções é que, por meios muito diferenciados, tanto Luiza quanto Ruy Belo elaboraram uma peculiaríssima obra, cada qual ao seu modo, de forma a conferir às suas escritas uma profunda fidelidade ao mundo que os cercava.

Ruy Belo, em entrevista, quando perguntado sobre "qual papel atribui à poesia no mundo de hoje", após alguma reflexão, encerra a sua resposta com a seguinte frase: "Em suma, no mundo de hoje a poesia deve fundamentalmente ser fiel à realidade.” (BELO, 2002, p. 24). O poeta, que apresenta em sua obra um manancial de referências de caráter religioso católico (sobretudo nos seus dois primeiros livros), embora se desvincule progressivamente desse universo temático, não o recusa em outros passos, ainda que não seja possível de modo algum circunscrever a sua criação no estreito espaço da "poesia religiosa". O que há de fato, parece-me, é uma problemática crise de consciência sobre a vida, o tempo e a finitude. A dimensão moral (essa, sim, encarregada pelo constrangimento institucional da Igreja) é dissolvida para dar espaço à reflexão ética, ou seja, o poeta afasta-se das soluções dogmáticas para se aproximar da especulação curiosa e espantada do pensamento poético-crítico - mesmo quando trata de problemas religiosos!

No poema "Corpo de Deus", a imagem que se nos revela é a de 
um eu lírico voltado à reles contemplação do crescimento da unha do pé, enquanto questões mais subidas lhe atravessam o pensamento no que se pode inferir dia de Corpus Christi.

A minha unha tem crescido tanto

e entretanto vim morrendo pouco a pouco

temi amei preocupei-me com problemas

fui feliz vivi a vida emocionei-me

Venceram-se diversas prestações

A minha poesia é por vezes mínima e mesquinha [...]

(BELO, 2009, p. 517)

O texto exemplar de Belo faz convergirem reflexões metafísicas (“e entretanto vim morrendo pouco a pouco"), notações corriqueiras ("Venceram-se diversas prestações") e apontamentos de uma arte poética (“A minha poesia é por vezes mínima e mesquinha”), tudo em uma meia dúzia de versos que abrem o seu "Corpo de Deus". Essa confusão entre assuntos os mais diversos provoca uma quebra da hierarquia entre os assuntos que supostamente seriam dignos de poesia. Tal ocorre porque o autor compõe conforme a profunda fidelidade ao real de que está cercado, e se o mundo em que está culturalmente situado lhe evoca a consciência do ciclo religioso por que passa o calendário cristão, é também verdade que o seu corpo testemunha (quase escrevo padece...) das paixões de uma vida que é sua e que um dia chegará ao fim: "Havia porventura de me recordar/ da ceia do senhor do pão do vinho?/ O meu pão é todo deste dia" (BELO, 2009, p. 517). O poeta se alimenta dos seus dias - mais especificamente deste dia, com o uso do dêitico a acentuar o espaço-tempo concreto e historicamente circunscrito pela voz da enunciação.

É por isso também que, em outro passo desse mesmo poema, o eu lírico inquira (a um passo da heresia) justamente do corpo de Deus: "Será e terá sido sempre assim com toda a gente?/ Cristo terá alguma vez sabido isso?/ Doer-lhe-ia o pé ao instituir a eucaristia?" (BELO, 2009, 
p. 517). A tripla interrogação progride no sentido de restituir a dimensão religiosa em que se inscreve o evento da eucaristia ao campo acessível do humano, quando, talvez com maior intensidade (ou fidelidade), a gente interpelada pelo sujeito lírico, assim como ele mesmo, possa comungar de uma experiência sagrada - mas de um sagrado do mundo.

Porventura isso a que eu chamo sagrado do mundo possa se esclarecer com a leitura de outro poema de Ruy Belo; este, muito mais contido na sua extensão. Refiro-me a "Requiem por um bicho": "Está tudo muito certo mas a gata/ que outro mundo trará a gata que morreu?" (BELO, 2009, p. 147). Nesse poema de dois versos, há pelo menos duas coisas acerca das quais gostaria de tratar: 1) o título, "Requiem por um bicho", é singularmente interessante pelo que nele se revela de uma tensão entre natureza e cultura. A parte natural, correspondente ao bicho que morreu, vem acompanhada do dado cultural, o réquiem, que necessariamente só poderia ser atribuída pelo humano - o sujeito lírico que evoca a morte do animal. Por isso mesmo, trata-se de um "requiem por um bicho", uma vez que os animais não são capazes, por si próprios, de fazer da morte uma experiência de cultura, de elaborar o luto; 2) em decorrência dessa mesma reflexão sobre a morte, a maneira como se constitui para o eu lírico a sua situação no mundo: “que outro mundo trará a gata que morreu?". Esse outro mundo pode ser lido também na tensão entre sagrado e profano, pois a inferência se suspende entre um mundo transcendente (o outro mundo como a outra vida, após a morte) e um mundo imanente, mas também outro, dado que transformado no tempo histórico pela ausência da gata.

Creio que, em ambos os casos (em que o outro mundo se pode ler), seja possível vislumbrar uma experiência do sagrado. No entanto, é no atrito provocado pelas duas perspectivas que noto aquilo que poderíamos designar um sagrado do mundo. O poema reforça tal reflexão na medida em que se apresenta interrogativamente; e o que eventualmente se perde da segurança dogmática é reabilitado pela potência poética de revelar 
sentidos - ainda que obscuros e indecisos - sobre a existência.

Outro nome incontornável da poesia dos anos 1960 é Herberto Helder. O poeta, estreado com a restrita publicação, em 1958, de um livreto com o poema $O$ amor em visita, traz à lume em 1961, com esse poema nele incluso, o seu $A$ colher na boca. A obra, que provocou uma pequena revolução no universo poético português, com efeito deixou marcas indeléveis nos autores que posteriormente se aventuraram no ofício de fazer versos. Nela encontramos uma prolífica fusão entre alquimia, magia e erotismo, que se constitui em uma cosmogonia própria, caracterizada por um excesso de imagens que ora pode remeter o seu leitor a uma herança surrealista, ora pode sugerir reflexos da estética do romantismo alemão. De todo modo, adentrar essa poesia é, antes de tudo, uma experiência singular de reconhecimento do mundo.

Às vezes estou à mesa: e cômo ou sonho ou estou somente imóvel entre a aérea felicidade da noite. O sangue do mundo corre e brilha. Porque a minha carne se distrai entre as coisas altas da primavera nocturna.

Ocupo-me nos símbolos, e gostaria que meu coração entontecesse lentamente, que meu coração caísse numa espécie de extática e sagrada loucura. (HELDER, 2009, p. 31)

Esses primeiros versos da sessão III do poema "O poema" nos dão a medida do que faz a poesia de Herberto Helder. A cena "à mesa" é apresentada em sua múltipla potencialidade sugestiva: trata-se de um espaço de comunhão, pois nela se come, mas também de um espaço de trabalho, no caso, trabalho poético a que associamos a referência ao verbo "sonhar" inscrito no primeiro verso. O dado lúdico/onírico propicia a 
profusão imagética pela qual o texto se desenvolve convulsamente, de maneira a constituir um vínculo mágico entre o sujeito e o cosmos: "O sangue do mundo corre/ e brilha.". Fator indicativo desse enlace cósmico é a ocupação "nos símbolos". O eu lírico não apenas maneja um arsenal simbólico, mas nele está ocupado, como quem habita uma casa - ou o próprio mundo.

Em conformidade com certa dicção rimbaudiana, é possível também traçar linhas de contato da poética de Herberto com aquela noção do "poeta vidente", movido pela força propulsora de um radical "desregramento dos sentidos". Esses topoi seriam rearticulados pela estética surrealista e chegariam à obra herbertiana embebida de um espírito de ancestralidade articulado pela dinâmica dos cultos erótico-dionisíacos. Georges Bataille, em sua obra Teoria da religião, descreve a experiência interior da vertigem religiosa de alguns povos arcaicos segundo esse mesmo princípio de "desregramento", próprio do êxtase místico e dos ritos sacrificiais (BATAILLE, 2016, p. 39). Pelo transe, o sacerdote (o poeta) alcança essa "espécie de extática e sagrada loucura", que, em outras palavras, podemos associar ao poder heurístico da linguagem. Sobre esse aspecto, Maria Lúcia Dal Farra afirma que

O poeta deve [...] experimentar as virtualidades da «vidência», do «outro», do «ver claro» e «lúcido», permitir-se passar por provas de desregramentos rigorosos, a fim de reter de si a quintessência, isso que o fará entrar em acorde com todos os seres. (DAL FARRA, 1986, p. 82).

Do primeiro ao último livro publicado, Herberto constituiu uma obra coesa, um verdadeiro mundo poético. Aliás, o autor assina em 1994 uma obra intitulada precisamente Do mundo, que tanto reforça a já referida dimensão cosmogônica da sua poesia como aponta para um desejo de assentar essa criação no plano imanente, em que se põe em cena o jogo de 
forças das relações humanas. Acerca da primeira obra, A colher na boca, um poeta e ensaísta como Luis Miguel Nava declara em texto crítico que “[a]ssiste-se, com ela, a um esvaziamento psicológico e biográfico do eu, cujos sentimentos são homologados a forças e energias que dele fazem uma espécie de palco onde os fluxos vitais adquirem um sentido cósmico." (NAVA, 2004, p. 194). E logo em sequência detalha: "O corpo passa [...] a ser predominantemente referido de maneira fragmentária, onde ganham especial importância não só as suas partes mais extremas [...], mas também as vísceras e os pontos através dos quais estas se abrem ao exterior [...]" (NAVA, 2004, p. 194).

Essa porosidade do corpo, que é contagiado e contagia o mundo exterior, assinalada por Nava, é uma das marcas mais candentes da poética herbertiana e decerto se repercute na poética do autor de Rebentação. Em sua arte poética "O real", lemos o seguinte:

\section{Levado e revolvido pelas vagas}

do real, estou como uma mesa posto até os ossos, empresto à página os meus ossos e ao escrever é como se tivesse a mão dentro dum espelho.

(NAVA, 2002, p. 115)

Observamos uma profunda manifestação do corpo, até os ossos, na escrita poética de Nava - corpo (como poucos na poesia portuguesa) aberto às intempéries do mundo. Os sentidos linguísticos constituídos por essa poética, com efeito, ganham uma maior intensidade quando compreendidos em tangência com os sentidos corporais, esses que nos surgem atravessados por variados elementos do mundo exterior e resultam na expressão de uma hipersensibilidade convulsa. O sujeito que se dobra na página, por meio da referência especular, não é tão somente projeção de uma alteridade da escrita, mas imagem de um duplo que se resulta dessa dinâmica entre interior/exterior, e que é marca basilar da poesia de Nava. 
Em muitos outros poemas, podemos notar como tal atravessamento entre interior e exterior revela de uma ânsia de Nava por registrar no corpo a sua escrita e o seu tempo. Ao seu modo, está posta uma forma de dizer o mundo em sua materialidade, de se implicar no real e dar de seu tempo histórico o testemunho (voltamos a Sena?), ainda que, muito benjaminianamente, tal testemunho seja o fracasso do discurso em replicar um mundo em ruína.

Mesmo as poéticas mais crentes (nas potencialidades da palavra e na capacidade humana de restituição pela linguagem da experiência vivida após séculos de barbárie) atestam essa fragilidade do discurso que, afinal de contas, não é mais que a fragilidade do nosso mundo. Um caso como, por exemplo, o de Daniel Faria que, em fins do século XX, quando a imagem do humano como nós o conhecíamos vinha à bancarrota e se anunciava a falência de qualquer projeto poético que se não quisesse absorver pelo mercado, conseguiu arrancar das suas palavras uma beleza invulgar de poeta moderno, não deixa de soar anacrônico, embora diga muito do nosso tempo e de certa nostalgia da evocação mágica, capaz de erguer como que uma atmosfera sagrada ao nosso redor. Não obstante esse quê de "condão de feitiçaria", a obra de Daniel Faria parece se abrir à incerteza e a certa precariedade, como é possível ler no poema "Homens que são como lugares mal situados”, que dá título ao livro homônimo de 1998:

Homens que são como lugares mal situados

Homens que são como casas saqueadas

Que são como sítios fora dos mapas

Como pedras fora do chão

Como crianças órfãs

Homens sem fuso horário

Homens agitados sem bússola onde repousem [...]

(FARIA, 2012, p. 15) 
A má situação do poema de Faria parece-me também uma forma de dizer o mundo, lugar mal situado por excelência. Lembro-me inevitavelmente de Sophia e do seu "Terror de te amar num sítio tão frágil como o mundo// Mal de te amar neste lugar de imperfeição/ Onde tudo nos quebra e emudece/ Onde tudo nos mente e nos separa." (ANDRESEN, 2018, p. 79). O poema de Coral me ilumina a leitura do texto de Faria que, a cada verso, compõe a imagem desses homens, sempre demarcados com um acento de negatividade, a quem falta alguma coisa, porque vivem no tempo dividido.

$\mathrm{Na}$ contramão do sentimento nostálgico de uma integridade perdida, os poetas surgidos em princípios do século XXI, remontando a certa tradição já instituída, pelo menos desde os anos 1970, pelos autores de Cartucho, tomam tal negatividade como princípio fundador de suas produções. A incorporação de um espírito de falência da poesia na própria poesia é típica dos autores reunidos na polêmica antologia organizada por Manuel de Freitas em 2001, Os poetas sem qualidades. O poeta de Vale de Santarém, que não possui nenhum poema antologizado no volume, é decerto uma figura já central no panorama da atual poesia portuguesa e mesmo referência para autores mais jovens. Ainda que, pela extensão do ensaio, não nos possamos aprofundar um pouco mais na sua obra, gostaria de destacar que Freitas, embora seja razoavelmente considerado persona non grata por alguns nomes mais antigos e estabelecidos pelo cânone, não constitui em sua obra verdadeira ruptura no contexto literário português, sobretudo se tivermos em vista o amplo quadro em que assomam as múltiplas vertentes da tradição moderna.

Encerro, portanto, esse rápido passeio por alguma poesia portuguesa pós-1961 com um excerto de poema de Freitas que comparece no livro Os infernos artificiais (paródia do referido Baudelaire, que deu início a esse trabalho): "No urinol público lia-se UTILIZAÇÃO GRATUITA./ Fiquei quase feliz (quantas coisas gratuitas/ há neste mundozinho de horror?). 
[...]" (FREITAS, 2007 p. 42). Afinal o mundo. Talvez não mais o mundo grandíloquo dos poemas dos primeiros modernos, mas um "mundozinho de horror", em um diminutivo que sentencia a pequenez a que ele foi reduzido.

\section{Referências:}

AGAMBEN, Giorgio. Profanações. Tradução e apresentação de Selvino J. Assmann. São Paulo: Boitempo, 2007.

ANDRESEN, Sophia de Mello Breyner. Coral e outros poemas. Seleção e apresentação de Eucanaã Ferraz. São Paulo: Companhia das Letras, 2018.

BARTHES, Roland. Aula. Tradução e posfácio de Leyla PerroneMoisés. São Paulo: Cultrix, 2013.

BATAILLE, Georges. Teoria da religião: seguida de Esquema de uma história das religiões. Tradução de Fernando Scheibe. Belo Horizonte: Autêntica Editora, 2016.

BELO, Ruy. Na senda da poesia. Lisboa: Assírio \& Alvim, 2002.

. Todos os poemas. Lisboa: Assírio \& Alvim, 2009.

CRUZ, Gastão. A quarta dimensão da poesia de Luiza Neto Jorge. In: Um corpo inenarrável e outras vozes: estudos de poesia portuguesa moderna e contemporânea. Organizado por Ida Alves. Niterói: EdUFF, 2010.

. A vida da poesia: textos críticos reunidos. Lisboa: Assírio \& Alvim, 2008.

. Poesia 1961-1981. Porto: O oiro do dia, 1983. [Com três desenhos de Manuel Baptista]

DAL FARRA, Maria Lúcia. A alquimia da linguagem: leitura da cosmogonia poética de Herberto Helder. Lisboa: Imprensa NacionalCasa da Moeda, 1986.

FARIA, Daniel. Homens que são como lugares mal situados. Belo Horizonte: Chão da Feira, 2012.

FREITAS, Manuel de. Poemas de Manuel de Freitas. In: Portugal 
0,1. Rio de Janeiro: Oficina Raquel, 2007.

HELDER, Herberto. Oficio cantante: poesia completa. Lisboa: Assírio \& Alvim, 2009.

JORGE, Luiza Neto. Poesia. Organização e prefácio de Fernando Cabral Martins. Lisboa: Assírio \& Alvim, 2001.

MAGALHÃES, Joaquim Manuel. Os dias, pequenos charcos. Lisboa: Editorial Presença, 1981.

MARTELO, Rosa Maria. Antecipações e retrospectivas: a poesia portuguesa na segunda metade do século XX. Revista Crítica de Ciências Sociais, n 74, p. 129-143, Junho de 2006.

NAVA, Luis Miguel. Ensaios reunidos. Prefácio de Carlos Mendes de Sousa. Lisboa: Assírio \& Alvim, 2004.

. Poesia completa. Prefácio de Fernando Pinto do Amaral; Organização e posfácio de Gastão Cruz. Lisboa: Dom Quixote, 2002.

PESSOA, Fernando. Obra em prosa. Rio de Janeiro: Nova Aguilar, 2005.

RÉGIO, José. "Literatura Viva”. presença: folha de arte e crítica. n 1, p. 1-8, 1927.

SENA, Jorge de. Antologia poética. Lisboa: Guimarães, 2010.

Artigo recebido em: 09/05/2020

Aprovado em: 29/07/2020 